\title{
МИТОПОЕТСКИ ПРОСТОР ТОПОНИМА У АНДРИЋЕВОМ ПРОЗНОМ ТЕКСТУ
}

У раду се врши етнолингвистичка анализа традиционалне топонимије ексцерпиране из Андрићевог приповједног дјела. Реконструише се митопоетска слика географског простора која се огледа у топонимији, разматрају се идеје и симболи у њој представљени, при чему се анализира концепција завјетног мјеста у српској топонимији.

Кључне ријечи: топоним, Андрић, семантичко поље, завјетно мјесто, нечисто мјесто, свето мјесто, мјесто смрти и покопа.

Српска народна топонимија је, као и код других народа, јединствен извор информација о духовној култури народа. Топоним је елемент неког концептуализованог подручја које је саставни дио народне културе, стога, остварење етнолингвистичког аспекта топонимских истраживања укључује разматрање принципа семантичке организације читавог топонимског континуума. „Можемо поставити питање која ријеч или комбинација ријечи, која врста ријечи могу бити географски називи. Анализа је показала да то на овом мјесту много зависи од карактера именованог објекта. Лично име увијек се суштински даје оним реалијама које се схватају као обје-

* bozcabk@yahoo.com 
кат. Што је конкретнији предмет, што се јасније издваја из околног пејзажа, тиме је већа његова способност да има своје име и тиме је разумљиво само име" (Суперанская 1985: 28).

С обзиром на топонимни материјал који проналазимо у Андрићевом приповједном тексту, истраживање се одвија методом индукције, гдје су полазна тачка топонимни подаци: посматрају се топоними који су на неки начин повезани са реализацијом појма натприродних особина локалитета. Прије него што пређемо на опис материјала напоменућемо да је „пред нама случај када у језичком систему нема адекватног израза за феномен, који је, несумњиво дио људске духовне културе. Ријеч је о тачкама у простору које могу бити означене као посе-

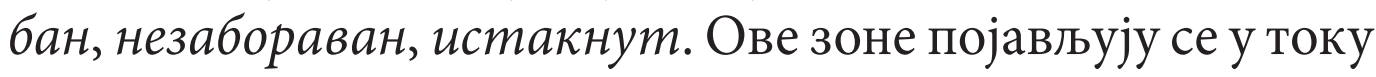
духовног савладавања простора у коме се као чворне тачке сматрају света и страшна мјеста"1 (Березович 1998: 252). Идеја о светом и страшном мјесту, а такође и о мјесту смрти и покопа, према Березович, обједињена је термином завјетно мјесто.

Тополексеме у чијој семантици постоје семе које откривају везу са идејом о посебно означеном локалитету, формирају семантичко поље завјетно мјесто. Као што сугерише материјал који проналазимо у Андрићевом приповједном тексту, у саставу тог макропоља могу се издвојити три поља - свето мјесто, нечисто мјесто, мјесто смрти или покопа (в. Березович 1998: 253). Посљедње се преклапа са прва два, али семантичке информације овдје формирају сопствени закони, стога ће ово поље бити разматрано одвојено.

Поставивши задатак идентификације топонимских средстава за обиљежавање завјетног мјеста, прво морамо одредити елементе одговарајућег оквира: сваки

1 Превод Б. К. 
од ових елемената има свој скуп репрезентативних лексема које представљају одређено семантичко микропоље. Комбинација микропоља даје одговарајуће семантичко поље $\mathrm{e}^{2}$, комбинација поља, заузврат, представља макро поље завјетно мјесто у топонимији. Установљена структура оквира има статус архетипског модела ситуације повезане са интеракцијом човјека и завјетног мјеста. При том се скуп, и посебно хијерархија компоненти структуре оквира за поднеске о светом мјесту, нечистом мјесту и мјестима повезаним с њима, смрт и покоп, не поклапа потпуно, стога ће одговарајуће поље бити описано одвојено. Истовремено, треба запамтити да проучавана поља имају зону пресјека, што је посљедица амбивалентности репрезентација о натприродном.

Структура семантичког поља може се описати не само као рефлексија идеје о одређеној ситуацији реалности, него и са тачке гледишта хијерархије конституената семантичких зона. Као што је познато, структура поља је хијерархијска: зона језгра најсигурније и адекватно карактерише назив поља, у периферним областима, веза са главном семантичком линијом је посреднија. У исто вријеме откривено је стремљење периферних локација ка другим пољима. Наравно, границе које раздвајају различите зоне једну од друге су условне: семантички простор не познаје граничне стубове, али се одликује глатким прелазом од једне смисаоне зоне ка другој. Имајући у виду конвенције ових граница, сматрамо потребним да их објаснимо, јер ће то помоћи да се извуку закључци о специфичностима избора топонимних информација о завјетном мјесту. Изолација у семантичком пољу појединачних зона заснована је на структурирању семантичког простора лексема које чине поље. У овом семантичком

2 О термну семантичко поље више видјети нпр. у: Прћић 1997: 107-111; Половина 1999: 18; Ковачевић 2012: 25-26. 
простору можемо приказати следеће зоне: сигнификативна зона (семе нечист, свет и сл. улазе у концептуално језгро значења лексема); конотативна зона (одговарајућа информације улази у зону конотације, која се може провјерити нпр. деривационим везама и сл.); асоцијативне зоне (информације су укључене у поље „даље” семантике, његов језички статус, иако врло низак, подржан је од стране стабилности одговарајућих асоцијација; зона маргиналних енциклопедијских информација (информација практично није верификована језичким средствима; одговарајуће везе су суштински егзистенцијалне, са минималном подршком на језичком нивоу) (Березович 2010: 102).

Дефинишући структуру оквира нечисто мјесто, примјећујемо да је основна компонента ове структуре извор нечистог својства локалитета (ово је нечиста сила или објекат који посједује неке натприродне карактеристике, перципиране као нечисте). Ако користимо у лингвистици признате термине описивања структуре ситуације, тада извор нечистих својстава локалитета преузима улогу субјекта ситуације. Тај субјекат дјелује на два начина: прво, дјелује на човјека изазивањем одговарајућих реакција, друго, нечисто може усмјерити своју енергију на сам географски објекат, дајући му одговарајућа својства. Тако се појављује следећа структура оквира нечисто мјесто:

\section{1. Извор нечистоће локалитета (нечисте силе):}

Олујаци су високо село. Да нису на једној стрмој проселини, могло би се рећи да су висока раван; овако, они су управо висока стрмен на високој равни. [...] Како се село сужава при крајевима, то издалека гледано личи на неку галију коју је гигантски и давно нестали талас неког потопа избацио и насукао на ову висију." - семантичко језгро поља: олуја - „врло снажан ветар са повременим 
ковитлацима, обично праћен грмљавином и падавинама" (РMC).

2. Карактеристике географског објекта због којих се сматра нечистим:

„Кажу да је једном један путник светачког лика рекао за Олујаке: Бог им је дао богатство и сваку несрећу. Ако је дотле било тако, после тога, извесно, никад се ништа није десило што би оповргло речи светог човека. [...] Олујачке куће су у већини на спрат, мање раштркане него у другим селима и, углавном, окупљене око Црног потока који протиче кроз село као осовина. [...] Сваки камен који је у додиру са његовом водом, превучен је црном кором као лишајем. Та вода није питка, и то знају деца која тек проходају." - језгро поља: несрећа, периферија поља: ирни;

3. Акције зле силе усмјерене на географски објекат: „Све у Олујацима добро расте, осим људи. Олујачки човјек је онизак, кривих ногу, широких али не правих леђа, широка лица са спљоштеним носом [...] Услед непрестаног пењања и спуштања, на које их је осудио положај њиховог села, они имају нарочито држање при ходу: цела горња половина тела им је забачена унатраг. Они су познати као сумњичави и тврди људи који мало говоре, ретко певају, увек раде [...] изгледа да нема Олујака који није или гушав или сакат или иначе ровашен.";

\section{4. Реакција особе на контакт са нечистим мјестом} (стања, емоције):

„Лепа Мостарка је доведена једно предвече у Олујаке. Довели су је млађи брат младожењин и један њезин рођак. [...] кад је почело пењање од Дрине до Олујака црвеном, готово окомитом стазом од спечене земље, удавача се поче побојавати да ће и крај овог нечовечног пута бити 
исти. Преварила се. Крај је био такав да је она већ сутрадан жалила каменито корито као јед зелене Дрине и стрми пут. [...] Кућа, младожења и чељад, све је било страшно, невероватно и неописиво. Праштајући се са рођаком грцала је без суза али очајнички. [...] И тако она, пошто се дању наради, леже у постељу с великим ножем и јадним, потајним лудаком поред себе. И плаче и дању и ноћу. Кад не успе да сакрије сузе, укућани јој кажу тупо и хладно да је то невестинско, да отплаче она док не проплаче дете." језгро поља: страх; периферија поља: очај, гриане, плач.

Ако оквир нечисто мјесто има прилично јасну структуру, онда је оквир свети простор много сложенији модел - нечиста мјеста се издвајају у природи, у околном пејзажу, они су заправо топографске реалије. Света мјеста су чешће повезана са културним реалијама споља унесеним у географски простор. Из тог разлога, топонимија је концентрисана не толико на опис специфичних својстава теренског елемента који доживљава као свети, колико на учвршћивање везе локалитета са култним објектом.

„Све што се рађало и живило у Бадемлића кући било је весело. [...] Само Ката Бадемлићка [...] била је изузетак. Није била срећна са човјеком, а није јој се дало у дјеци. [...] У првих дванаест година изродивала је деветеро дјеце, готово све мушке, и сва су јој редом умирала кад би дошла у најљепше године. После десетог дјетета једва остаде жива. [...] То посљедње дијете било је женско, и оно остаде живо. [...] Али кад јој би око шест година, поче да опада и ружња. Сад јој је била петнаеста година. Али се слабо развијала тјелесно, и још слабије душевно. А стара Бадемлићка ју је сама преносила, хранила, мила и пресвлачила."

Структура оквира светог мјеста је следећа:

\section{1. Култна дјелатност: завјет, молитва}

„Она се једног дана пред Богородичиним олтаром завјетовала да ће о Малој Госпојини боса отићи у Олово 
и одвести болесну кћер Госпином врелу код манастира. [...] Кад је учинила завјет, дуго се још молила, а кад се дигла, поновила је своју молитву Богородици. - Ја више не могу. Него, дај од два дермана један: или ми је оздрави, или је узми себи, у рај, као и оно деветеро.

2. Карактеристике особина топографске реалије која га је учинила светим простором (веза са култним објектом, својства топографске стварности):

„Око манастирских рушевина и пресвођеног басена, из којег се мукло чуло како пада топла вода Госпина врела, био је цио један вашар свијета, [...] Наизмјенице су се купали, мушкарци па жене. [...] Нероткиње чуче до врата у води и склопљених очију шапућу молитве. Неке хватају воду с млаза у дланове и испирају грло, уши, ноздрве, и свака је толико заузета мишљу о оздрављењу."

\section{3. Необичан догађај:}

Дјевојчица викну одједном и неочекивано јасним и продорним гласом: - Ено га, силази на облацима! Исусе! Исусе!

Мјесто смрти и покопа се не могу недвосмислено приписати нечистом или светом, па ћемо овај материјал размотрити одвојено. У оквиру ове области, према Березович (2010: 137-153), могу се разликовати три микропоља: хришћанско (православно) гробле, мјесто нетрадиционалног покопа, мјесто смрти. За ову прилику навешћемо примјер у топонимној номинацији којим је означено мјесто смрти - насилно или претрпљено као резултат несреће.

„У једног инжињера била је жена, мађарска Јеврејка, витка љепотица, крупних очију и велике косе [...] она се заволила с једним риђим, као кап младим потпоручником. На врху Боровца (микропоље: мјесто смрти), пуном стаза и младих борића (карактеристика локали- 
тета) нашли су их једног дана обоје мртве. Он је убио њу, па себе (ситуација смрти).”

У топонимима које проналазмо у Андрићевом дјелу, релевантне информације концентрисане су у оквиру семантичког макропоља, завјетно мјесто, које је, пак, подијељено на три сегмента: нечисто мјесто, свето мјесто, мјесто смрти и покопа. Границе поља одређују се уносом информација о завјетном мјесту у семантички простор топонима, а хијерархија елемената поља мјестом које та информација заузима у семантици топонима. Другим ријечима, структура поља одговара семантичкој организацији својих саставних елемената. Поред хијерархијских односа, које формирају „вертикале” семантичког поља, његови параметри су такође постављени структуром тог фрагмента слике свијета који се описује семантичким пољем. Ова когнитивна структура представља одговарајући оквир. Стога су истраживана поља анализирана у три правца: састав поља, хијерархија елемената, структура оквира. Најразвијеније у топонимској номинацији је семантичко поље нечисто мјесто. Овдје је различито представљена структура ситуације која описује интеракцију особе са нечистим локалитетом. Он је нечист и одређен је извором нечистоће - нечисте силе, које карактеришу радње које упућују на географски објекат или се манифестују у вези с њим, а такође човјекова реакција на контакт са „страшним мјестом”, указују на особине географског објекта због перцепције о њему као нечистом. Структура оквира поља свето мјесто много је мање развијена. Одговарајући оквир обухвата сљедеће елементе: особине локалитета, које су разлози његове перцепције као светог: а) одговарајуће особине; б) комуникација са култним објектом, култна активност, феноменални догађај. Поље мјесто смрти и покопа обухвата три дјела: хришћанско гробле, мјесто нетрадиицоналног покопа, мјесто смрти. Елементи структуре 
оквира имају различите активности у различитим дијеловима, па је тако у дијелу мјеста смрти најразвијенија ситуација смрти. Ово поље је направљено другачије од претходних, јер у свој централни дио укључује директне ознаке култних предмета.

Један од живих и моћних говорних елемената који подржавају живот топонима или им дају живот, представљају књижевноумјетничка дјела. Топоними у умјетничком тексту, у складу са законима организације текста, претварају се у носиоце писаних информација, а такође утичу и на садржај кроз функцију указивања на текстни простор. Сходно томе, функција топонима у умјетничком дјелу није само именовање било каквог мјеста, него и утицај на информативност текста кроз своју семантику. Истраживачи, неријетко, прилично наглашавају како антропоними и топоними учествују у стварању умјетничких слика хероја и формирању умјетничког хронотопа простора и времена, те служе откривању идеолошког и естетског садржаја текста и идентификовању скривеног значења, што је једна од веома битних особина Андрићевог приповједачког стила. Ако узмемо у обзир националне топониме са становишта унутартекстуалне стилистике, можемо рећи да ови топоними играју улогу везе између прошлости и садашњости и могу послужити као симбол завичаја, што се очигледно потврђује на ексцерпираним примјерима.

\section{Закључак}

У топонимима које проналазимо у Андрићевом прозном дјелу релевантне информације су концентрисане у оквиру семантичког макропоља, „завјетно мјесто”, које је, пак, подијељено у три засебна сегмента: „нечисто мјесто”, „свето мјесто”, „мјесто смрти и покопа”. Структура 
поља одговара семантичкој организацији својих саставних елемената. Поред хијерархијских односа, које формирају вертикале семантичког поља, његови параметри су такође постављени структуром тог фрагмента слике свијета који се описује семантичким пољем. Ова когнитивна структура представља одговарајући оквир. Стога су истраживана поља анализирана у три правца: састав поља, хијерархија елемената, структура оквира. Најразвијеније у топонимској номинацији је семантичко поље „нечисто мјесто”, док је структура оквира поља „свето мјесто” много мање развијена. Поље „мјесто смрти и покопа" је направљено другачије од претходних, јер у свој централни дио укључује директне ознаке култних предмета. Функција топонима у умјетничком дјелу није само именовање било каквог мјеста, него и утицај на информативност текста кроз своју семантику. Топоними у Андрићевом прозном тексту учествују у стварању умјетничких слика и формирању умјетничког простора и времена, те служе откривању идеолошког и естетског садржаја текста и идентификовању скривеног значења.

\section{Извор}

Иво Андрић, Сабране приповетке, друго, допуњено здање, Београд: Завод за уџбенике, 2012.

\section{Литература}

Березович 2010: Е. Л. Березович, Русская топонимия в этнотингвистическом аспекте, Мифопоетический образ пространства, Москва: URSS.

Березович 1998: Е. Л. Березович, Топонимия Русского Севера, этнолингвистические исследования, Екатеринбург: Издательство Уральского университета. 
Ковачевић 2012: М. Ковачевић, Узрочно семантичко поле, Београд: Јасен.

Половина: В. Половина, Семантика и текстлингвистика, Београд: Чигоја.

Прћић 1997: Т. Прћић, Семантика и прагматика речи, Сремски Карловци - Нови Сад: Издавачка књижарница Зорана Стојановића.

PMC: Речник српскога језика, Нови Сад: Матица српска, 2011. Суперанская 1985: А. В. Суперанская, Что такое топонимика?, Москва: Наука.

\section{Božica Knežević}

\section{MYTHOPOETIC SPACE OF TOPONYMS IN IVO ANDRIĆ'S PROSE}

In the case of the toponyms we can find in the prose work of Ivo Andrić, relevant information are focused in the framework of the semantic macro field, "votive place", which is divided into three different segments: „impure place”, „sacred place”, „place of death and burial". The structure of the fields matches semantic organization of its constituent parts. Apart from hierarchical relations, which form verticals of the semantic field, its parameters are put according to the fragment's structure of the picture of the world that is described by the semantic field. This cognitive structure represents certain framework. Thus, researched fields are analyzed into three directions: content of the field, hierarchy of the elements, and the structure of the framework. "Impure place" is the most developed semantic nomination, while the framework structure of the field "sacred place" is less developed. The field "place of death and burial" is structured differently in comparison to the previous ones, because in its central part it denotes direct mark of cult subjects. The function of the toponyms in artistic works is not only naming any place, but the influence on informativeness of the text trough its semantic. Toponyms in the Ivo Andrić's prose work participate 
in creation of the artistic pictures and creation of the artistic space and time, and serve in revealing of the ideological and aesthetic contents and identification of hidden meaning. 